IZA DP No. 10241

Labor Market Imperfections and the Firm's Wage Setting Policy

Sónia Félix

Pedro Portugal

September 2016 


\title{
Labor Market Imperfections and the Firm's Wage Setting Policy
}

\author{
Sónia Félix
}

Banco de Portugal

and Nova SBE

Pedro Portugal

Banco de Portugal,

Nova SBE and IZA

\section{Discussion Paper No. 10241 \\ September 2016}

\author{
IZA \\ P.O. Box 7240 \\ 53072 Bonn \\ Germany \\ Phone: +49-228-3894-0 \\ Fax: +49-228-3894-180 \\ E-mail: iza@iza.org
}

Any opinions expressed here are those of the author(s) and not those of IZA. Research published in this series may include views on policy, but the institute itself takes no institutional policy positions. The IZA research network is committed to the IZA Guiding Principles of Research Integrity.

The Institute for the Study of Labor (IZA) in Bonn is a local and virtual international research center and a place of communication between science, politics and business. IZA is an independent nonprofit organization supported by Deutsche Post Foundation. The center is associated with the University of Bonn and offers a stimulating research environment through its international network, workshops and conferences, data service, project support, research visits and doctoral program. IZA engages in (i) original and internationally competitive research in all fields of labor economics, (ii) development of policy concepts, and (iii) dissemination of research results and concepts to the interested public.

IZA Discussion Papers often represent preliminary work and are circulated to encourage discussion. Citation of such a paper should account for its provisional character. A revised version may be available directly from the author. 
IZA Discussion Paper No. 10241

September 2016

\section{ABSTRACT}

\section{Labor Market Imperfections and the Firm's Wage Setting Policy*}

We use matched employer-employee data and firm balance sheet data to investigate the importance of firm productivity and firm labor market power in explaining firm heterogeneity in wage formation. We use a linear regression model with one interacted high dimensional fixed effect to estimate 5-digit sector-specific elasticity of output with respect to input factors directly from the production function. This allows to derive firm specific price-cost mark-up and elasticity of labor supply. The results show that firms possess a considerable degree of product and labor market power. Furthermore, we find evidence that firm's monopsony power affects negatively the earnings of its workers and firm's total factor productivity is considerably associated with higher earnings, ceteris paribus. We also find that firms use monopsony power for wage differentiation between male and female workers.

JEL Classification: J31, J20, J42

Keywords: monopsony, wage setting, labor market frictions

Corresponding author:

Pedro Portugal

Banco de Portugal

Av. Almirante Reis, 71-6th floor

1150-165 Lisboa

Portugal

E-mail: pportugal@bportugal.pt

\footnotetext{
* Financial support from Fundação para a Ciência e Tecnologia is acknowledged. The views expressed are those of the authors and do not involve the responsibility of the Banco de Portugal or the Eurosystem. An earlier version of this paper circulated under the title "Firm monopsony power and the wage setting policy".
} 


\section{Introduction}

A central feature of perfectly competitive markets is that markets clear meaning that all workers with similar quality should be paid the same market clearing wage. The assumption of a single market wage that would cause all employees to leave instantaneously the firm after a one cent wage cut seems unrealistic. Recent empirical evidence suggests the presence of considerable wage dispersion among workers with similar characteristics and among similar firms. Torres, Portugal, Addison, and Guimarães (2012) use a longitudinal matched employer-employee dataset for Portugal to estimate a wage equation with three high-dimensional fixed effects and decompose the variation in real hourly wages into three different components related to worker, firm and job title heterogeneity. The authors find that worker permanent heterogeneity accounts for about 36 percent of wage variation, firm permanent effects account for almost 29 percent and job title effects are less important but still explaining almost 10 percent of wage variation.

The firm effects estimated in wage regressions can be thought as arising from distortions in the labor markets (Abowd, Finer, and Kramarz (1999) and Goux and Maurin (1999)). Search frictions in the labor market such as imperfect information on alternative available jobs (Burdett and Mortensen (1998) and Shimer (2005)), moving and learning costs (Boal and Ransom (1997)), firm specific human capital, reputation costs, exploitation of rents, and worker heterogenous preferences namely over nonwage job characteristics (Stevens (1994) and Bhaskar, Manning, and To (2002)) are sources of labor market power and help to explain why firms have market power and why the labor supply curve faced by an individual firm is not perfectly elastic. These search frictions in the labor market may generate upward sloping labor supply curves to a particular firm. In a standard wage setting model this means that firms possess some power to mark down their wages below the marginal revenue product. This is in line with the "new monopsony" literature popularized by Manning (2003) where employers gain some market power derived from search frictions when setting wages. Monopsony is not understood in the traditional sense of a unique employer in the labor market but instead as synonymous of imperfect competition, monopsonistic competition, upward sloping labor supply curve to the firm, or finite labor supply elasticity. A particular firm may face an upward labor supply curve even if there is no concentration on the 
demand side of the market.

Recent empirical literature provide robust evidence consistent with the existence of monopsony power and upward-sloping labor supply curves to individual firms. There is considerable heterogeneity in the estimated labor supply elasticity. Ransom and Oaxaca (2010), Hirsch, Shank, and Schnabel (2010) and Weber (2013) estimate the labor supply elasticity to range between 1 to 10. Dobbelaere and Mairesse (2011) estimate a production function for 38 French manufacturing industries and derive product and labor market imperfection parameters as a wedge between the factor elasticities and their corresponding shares in revenue. Then, the authors classify each industry into six different regimes according to the type of competition in the product and the labor market (perfect vs. imperfect competition in the product market and efficient bargaining vs. right to manage or perfect competition vs. monopsonistic competition in the labor market). Their analysis of the within-regime firm heterogeneity through the Swamy methodology suggests considerable dispersion in the estimated price-cost mark-up and rent-sharing or labor supply elasticity parameters. Depew and Sørensen (2013) use employee records both from Ford Motors in Michigan and A. M. Byers in Pennsylvania and find that the workers' labor supply elasticity to a firm is counter-cyclical so that monopsony power is pro-cyclical. The estimates of the labor supply elasticity to the firm are typically between 4 during expansions and 1.6 during recessions.

The primary contribution of this study is twofold: first, we estimate a measure of labor supply elasticity to the firm directly from the production function and at a very granular level (by estimating a standard production function using the one-iterative high dimensional estimation procedure and considering the 5-digit sector variable as interaction variable) which allows to account for the heterogeneity across and within labor markets in the analysis; second, and to the best of our knowledge, this is the first study that disentangles the importance of firms' wage setting power and firm's total factor productivity to explain the firms' wage setting policies.

In this study we use employer-employee matched data and firm balance sheet data to obtain an empirical distribution of the firm specific product and labor market imperfection parameters as directly estimated from the production function, following the theoretical framework developed by Dobbelaere (2004) and Dobbelaere and Mairesse (2011) and using the high dimensional fixed effects estimation procedure 
proposed by Portugal and Guimarães (2010). We proceed by estimating the impact of monopsony power on the firms' wage setting policy by plugging the estimated labor supply elasticity and the firm total factor productivity in a Mincer wage equation. We also estimate the importance of rent-sharing to explain wage formation within the efficient bargaining setting. Furthermore, we use the Gelbach's methodology (Gelbach (2014)) to decompose the impact of the estimated labor supply elasticity on wages within the firm, worker, and job title dimensions.

In fact, scarce empirical literature can be found on the effects of monopsonistic competition on earnings of individuals. Weber (2013) estimates firm-level labor supply elasticities for the U.S. labor market through an extension of the dynamic model of labor supply proposed by Manning (2003) and examines the effects of monopsonistic competition on the earnings distribution. The author provides evidence of substantial heterogeneity in the market power possessed by firms and show a positive relationship between the firm's labor supply elasticity and the wages of its workers. The author estimates that the impact of a one unit increase in a firms' labor supply elasticity is associated with an increase in earnings that ranges from 5 to 16 percent.

We find strong evidence that the firm elasticity of labor supply is positively and significantly related to wages meaning that firms with more monopsonistic power pay on average lower wages, ceteris paribus. We also find that the elasticity of labor supply to the firm affects wages differently according to the gender of workers which evidences the importance of considering the firm's labor market power when studying the wage pay gap between women and men. In turn, and surprisingly, our results suggest that firms with higher relative extent of rent-sharing pay lower wages. We also show that firm productivity contributes considerably to explain heterogeneity in wage formation in both labor market settings.

The paper proceeds as follows. In the next section we briefly present the theoretical framework. This is followed by a discussion of the data used in the empirical analysis and the estimation procedure. Sections 4 and 5 report the results on the estimation of the labor and product market imperfection parameters and firms' total factor productivity, respectively. Section 6 presents the wage regressions. Section 7 discusses the results and section 8 concludes. 


\section{Theoretical framework}

We closely follow Dobbelaere and Mairesse (2011) to jointly estimate product and labor market imperfections as a wedge between factor elasticities for labor and materials in the production function and their corresponding shares in revenue. This approach extends the framework of Hall (1988) abstaining from the assumption of perfect competition in the labor market and builds on the estimation of the firm price-cost mark-up and rent-sharing parameters directly from the production function. The analysis relies crucially on the insight that output elasticities of labor and materials are equal to their revenue shares when prices equal the marginal cost of production.

We consider a production function $\mathcal{Q}_{f t}=\Theta_{f t} F\left(N_{f t}, M_{f t}, K_{f t}\right)$, where $\mathcal{Q}_{f t}$ represents physical output of firm $f$ in period $t$, and $\mathrm{F}($.$) is a function of labor N_{f t}$, materials $M_{f t}$, and capital $K_{f t}$. The term $\Theta_{f t}=A \exp \left(\eta_{f}+\nu_{t}+u_{f t}\right)$ is the Hicksian neutral shift of firm $f$ in period $t, \eta_{f}$ is an unobserved firm-specific time-invariant effect, $\nu_{t}$ is a set of time effects, and $u_{f t}$ is a firm-year idiosyncratic disturbance term with the conventional properties.

Taking natural logarithms on both sides of the production function and denoting $q_{f t}, l_{f t}, m_{f t}, k_{f t}$, and $\theta_{f t}$ the logarithm of $\mathcal{Q}_{f t}, N_{f t}, M_{f t}, K_{f t}$, and $\Theta_{f t}$, respectively, results in a linear production function

$$
q_{f t}=\left(\varepsilon_{N}\right)_{f t} n_{f t}+\left(\varepsilon_{M}\right)_{f t} m_{f t}+\left(\varepsilon_{K}\right)_{f t} k_{f t}+\theta_{f t}
$$

where $\varepsilon_{J}(J=N, M, K)$ is the factor-cost elasticity of output with respect to input factor $J$.

\subsection{Perfect competition in the product and labor market}

In perfectly competitive labor and product markets, where firms are price-takers in the product and input factor markets, short-run profit maximization implies that: 


$$
\begin{aligned}
& \left(\varepsilon_{N}\right)_{f t}=\frac{w_{f t} N_{f t}}{P_{f t} \mathcal{Q}_{f t}} \equiv\left(\alpha_{N}\right)_{f t} \\
& \left(\varepsilon_{M}\right)_{f t}=\frac{j_{f t} M_{f t}}{P_{f t} \mathcal{Q}_{f t}} \equiv\left(\alpha_{M}\right)_{f t}
\end{aligned}
$$

where $w_{f t}$ and $j_{f t}$ represent labor and material factor prices, respectively, and $P_{f t}$ is the price of output. Therefore, $\left(\alpha_{N}\right)_{f t}$ and $\left(\alpha_{M}\right)_{f t}$ are the firm shares of labor and material costs in total revenue, respectively.

Assuming that the elasticity of scale is known $(\lambda)$, the elasticity of capital can be written as:

$$
\left(\varepsilon_{K}\right)_{f t}=\lambda_{f t}-\left(\alpha_{N}\right)_{f t}-\left(\alpha_{M}\right)_{f t}
$$

Then, combining equation (2) with equation (1) yields:

$$
q_{f t}-k_{f t}=\left(\alpha_{N}\right)_{f t}\left[n_{f t}-k_{f t}\right]+\left(\alpha_{M}\right)_{f t}\left[m_{f t}-k_{f t}\right]+\left[\lambda_{f t}-1\right] k_{f t}+\theta_{f t}
$$

\subsection{Imperfect competition in the product market}

\subsubsection{Perfectly competitive labor market}

In turn, if firms act as price-setters in the product market but price-takers in the input factor markets, profit maximization leads to:

$$
\begin{aligned}
& \left(\varepsilon_{N}\right)_{f t}=\mu_{f t}\left(\alpha_{N}\right)_{f t} \\
& \left(\varepsilon_{M}\right)_{f t}=\mu_{f t}\left(\alpha_{M}\right)_{f t},
\end{aligned}
$$

where $\mu_{f t}=\frac{P_{f t}}{\left(C_{Q}\right)_{f t}}>1$ refers to the mark-up of price $(P)$ over marginal cost $\left(C_{Q}\right)$. In this setting, the capital-output elasticity can be written as:

$$
\left(\varepsilon_{K}\right)_{f t}=\lambda_{f t}-\mu_{f t}\left(\alpha_{N}\right)_{f t}-\mu_{f t}\left(\alpha_{M}\right)_{f t}
$$

and equation (3) can be rewritten as: 


$$
q_{f t}-k_{f t}=\mu_{f t}\left[\left(\alpha_{N}\right)_{f t}\left[n_{f t}-k_{f t}\right]+\left(\alpha_{M}\right)_{f t}\left[m_{f t}-k_{f t}\right]\right]+\left[\lambda_{f t}-1\right] k_{f t}+\theta_{f t}
$$

Therefore, the mark-up of price over marginal cost can be estimated using the previous equation ${ }^{1}$.

\subsubsection{Efficient bargaining}

In this setting, risk-neutral workers and the firm bargain over wages and employment. Workers maximize $U\left(w_{f t}, N f t\right)=N_{f t}\left(w_{f t}-\bar{w}_{f t}\right)$ where $\bar{w}_{f t}<w_{f t}$ is the reservation wage. Given that capital is assumed to be quasi-fixed, the firm wants to maximize short-run profits $\Pi_{f t}=R_{f t}-w_{f t} N_{f t}-j_{f t} M_{f t}$, where $R_{f t}=P_{f t} \mathcal{Q}_{f t}$ is the firm total revenue. The outcome of the bargaining is the generalized solution to the following maximization problem:

$$
\max _{w_{f t}, N_{f t}, M_{f t}}\left\{N_{f t}\left(w_{f t}-\bar{w}_{f t}\right)\right\}^{\phi_{f t}}\left\{R_{f t}-w_{f t} N_{f t}-j_{f t} M_{f t}\right\}^{1-\phi_{f t}}
$$

The first order condition for material input is given by equation (5) because material input is unilaterally determined by the firm. Setting the relative extent of rent-sharing equal to $\gamma_{f t}=\phi_{f t} /\left(1-\phi_{f t}\right)$ and denoting the marginal revenue product of labor as $\left(R_{N}\right)_{f t}$, the first order conditions with respect to wage and labor are, respectively,

$$
\begin{gathered}
w_{f t}=\bar{w}_{f t}+\gamma_{f t}\left[\frac{R_{f t}-w_{f t} N_{f t}-j_{f t} M_{f t}}{N_{f t}}\right] \\
w_{f t}=\left(R_{N}\right)_{f t}+\phi_{f t}\left[\frac{R_{f t}-\left(R_{N}\right)_{f t} N_{f t}-j_{f t} M_{f t}}{N_{f t}}\right]
\end{gathered}
$$

which yield the following contract curve:

$$
\left(R_{N}\right)_{f t}=\bar{w}_{f t}
$$

\footnotetext{
${ }^{1}$ In the right-to-manage bargaining framework, the firm can bargain with risk-neutral workers over wages but retains the right to set employment afterwards unilaterally. Since the firm uniquely sets the amount of labor and material inputs to contract, this is equivalent to perfect competition in the labor market and equation (7) still provides an estimate of the mark-up $\mu_{f t}$.
} 
Given that in equilibrium $\mu_{f t}=\frac{P_{f t}}{\left(R_{\mathcal{Q}}\right)_{f t}}$, where $\left(R_{\mathcal{Q}}\right)_{f t}$ is the marginal revenue, the marginal revenue of labor can be expressed as the product of marginal revenue and marginal product of labor, $\left(\mathcal{Q}_{N}\right)_{f t}$ :

$$
\left(R_{N}\right)_{f t}=\left(R_{Q}\right)_{f t}\left(Q_{N}\right)_{f t}=\left(R_{Q}\right)_{f t}\left(\varepsilon_{N}\right)_{f t} \frac{\mathcal{Q}_{f t}}{N_{f t}}=\frac{P_{f t}\left(\mathcal{Q}_{N}\right)_{f t}}{\mu_{f t}}
$$

Combining equation (11) with equation (12) yields:

$$
\left(\varepsilon_{N}\right)_{f t}=\mu_{f t}\left(\frac{\bar{w}_{f t} N_{f t}}{P_{f t} \mathcal{Q}_{f t}}\right)=\mu_{f t}\left(\bar{\alpha}_{N}\right)_{f t}
$$

which is equivalent to:

$$
\left(\varepsilon_{N}\right)_{f t}=\mu_{f t}\left(\alpha_{N}\right)_{f t}-\mu_{f t} \gamma_{f t}\left[1-\left(\alpha_{N}\right)_{f t}-\left(\alpha_{M}\right)_{f t}\right]
$$

The previous equation shows that employment does not directly depend on the bargained wage. The elasticity of capital is given by:

$$
\left(\varepsilon_{K}\right)_{i t}=\lambda-\mu_{i t}\left(\alpha_{N}\right)_{i t}+\mu_{i t} \gamma_{i t}\left[1-\left(\alpha_{N}\right)_{i t}-\left(\alpha_{M}\right)_{i t}\right]-\mu_{i t}\left(\alpha_{M}\right)_{i t}
$$

and the corresponding modified production function can be expressed as:

$$
q_{f t}-k_{f t}=\left(\varepsilon_{N}\right)_{f t}\left[n_{f t}-k_{f t}\right]+\left(\varepsilon_{M}\right)_{f t}\left[m_{f t}-k_{f t}\right]+\left[\lambda_{f t}-1\right] k_{f t}+\theta_{f t}
$$

This equation allows the identification of the mark-up of price over marginal cost as well as the labor market imperfections parameter as measured by the extent of rent-sharing parameter.

The authors derive a joint market imperfections parameter $(\psi)$ through the comparison between the factor elasticities as directly estimated from the production function and the factor shares for labor and materials. The sign and significance of this parameter characterize the type of competition in the product and labor markets:

$$
\psi_{f t} \equiv \frac{\left(\varepsilon_{M}\right)_{f t}}{\left(\alpha_{M}\right)_{f t}}-\frac{\left(\varepsilon_{N}\right)_{f t}}{\left(\alpha_{N}\right)_{f t}}
$$

In the efficient bargaining setting: 


$$
\psi_{f t} \equiv \frac{\left(\varepsilon_{M}\right)_{f t}}{\left(\alpha_{M}\right)_{f t}}-\frac{\left(\varepsilon_{N}\right)_{f t}}{\left(\alpha_{N}\right)_{f t}}=\mu_{f t} \gamma_{f t}\left[\frac{1-\left(\alpha_{N}\right)_{f t}-\left(\alpha_{M}\right)_{f t}}{\left(\alpha_{N}\right)_{f t}}\right]
$$

If $\psi$ is positive then an efficient bargaining model prevails and we can derive estimates for the price-cost markup and the (absolute and relative) extent of rentsharing parameters. In this case the worker gets a wage higher than her marginal revenue and, therefore, the ratio between the output elasticity of labor and the share of labor costs in revenue becomes smaller than the respective ratio for materials.

\subsection{Monopsony}

In this study we analyse the importance of firm labor market power in explaining the wage setting policy followed by firms and, therefore, we focus our analysis on the monopsony regime. The theoretical framework for the monopsony model can be described as follows. Consider a firm that operates under imperfect competition in the product market and faces a labor supply $N_{f t}\left(w_{f t}\right) . N_{f t}$, the labor supply curve of the individual firm, is an increasing function of the wage, $w_{f t}$. The short-run profit function for the monopsonist firm taking the labor supply as given is:

$$
\max _{N_{f t}, M_{f t}} \Pi\left(w_{f t}, N_{f t}, M_{f t}\right)=R_{f t}\left(N_{f t}, M_{f t}\right)-w_{f t}\left(N_{f t}\right) N_{f t}-j_{f t} M_{f t}
$$

The first order condition with respect to the material input leads to $\left(R_{M}\right)_{f t}=j_{f t}$ with the marginal revenue of materials $\left(R_{M}\right)_{f t}$ equal to the price of materials $j_{f t}$ (equation (5)). The first order condition with respect to the labor input is given by:

$$
w_{f t}=\beta_{f t}\left(R_{N}\right)_{f t}, \beta_{f t} \equiv \frac{\left(\varepsilon_{w}\right)_{f t}}{1+\left(\varepsilon_{w}\right)_{f t}}
$$

where $\left(\varepsilon_{w}\right)_{f t} \in \mathcal{R}_{+}$is the wage elasticity of the labor supply. The firm's degree

of monopsony power can be measured by $\frac{\left(R_{N}\right)_{f t}}{w_{f t}}$ and therefore the more inelastic the labor supply the larger the gap between the marginal revenue of labor and the wage. This means that the monopsony power depends negatively on the elasticity of the labor supply.

Equation (20) can be rewritten as: 


$$
\left(\varepsilon_{N}\right)_{f t}=\mu_{f t}\left(\alpha_{N}\right)_{f t}\left(1+\frac{1}{\left(\varepsilon_{w}\right)_{f t}}\right)
$$

Then, under monopsony, estimating equation (16) yields an estimate of the markup of price over marginal cost and of the labor supply elasticity to the firm. Moreover, the parameter of joint market imperfections is given by:

$$
\psi_{f t} \equiv \frac{\left(\varepsilon_{M}\right)_{f t}}{\left(\alpha_{M}\right)_{f t}}-\frac{\left(\varepsilon_{N}\right)_{f t}}{\left(\alpha_{N}\right)_{f t}}=-\mu_{f t} \frac{1}{\left(\varepsilon_{w}\right)_{f t}}
$$

In this setting we expect $\psi$ to be negative and labor market frictions generate upward-sloping labor supply curves to individual firms giving some degree of market power to employers. In the monopsony setting, the marginal employee receives a wage that is less than her marginal revenue.

\section{Data description}

In the first part of this study we use the Portuguese dataset Simplified Corporate Information - IES (Portuguese acronym for Informação Empresarial Simplificada) which virtually covers the population of Portuguese nonfinancial corporations ${ }^{2}$. Data is compiled and disseminated by Statistics Portugal (Instituto Nacional de Estatística (INE)) and consists in a new system to collect firm mandatory annual economic, financial and accounting information for a single moment and to a single entity.

Firms report detailed balance sheet information as well as information on a set of important variables, namely employment and transactions of goods and services by geographical area. Even though data on IES started being collected in 2006, there was a report collecting data in 2005 which was also taken into consideration in the analysis. We get an unbalanced panel of nonfinancial Portuguese firms spanning eight years. We restrict our sample to manufacturing firms with at least 6 years of observations for identification purposes. We only consider observations with nonzero sales, capital, or number of employees, and observations with factor shares of labor or materials

\footnotetext{
${ }^{2}$ The sampling method consists of non-financial corporations covering all sectors of activity defined in the Portuguese Classification of Economic Activities with the following exceptions: financial intermediation, general government, private households with employed persons, and international organizations and other non-resident institutions.
} 
inside the unit interval. Also, we consider 1 and 99 percentiles as cutoff levels for output and input growth rates. We use sales as the measure of output $(\mathcal{Q})$, labor is the average number of employees $(N)$, capital is the net book value of fixed assets $(K)$, and material is intermediate consumption $(M)$.

The main descriptive statistics of the variables included in the analysis are reported in Table 1. The shares of labor and materials in output are obtained by dividing the firm total labor cost and intermediate consumption, respectively, by the firm production as measured by firm sales.

Table 1 - Main summary statistics

\begin{tabular}{lccccc}
\hline & \multicolumn{5}{c}{$2006-2012$} \\
\cline { 2 - 6 } & Mean & St. Dev. & $Q_{1}$ & $Q_{2}$ & $Q_{3}$ \\
\hline$\Delta_{q}:$ Output growth & 0.015 & 0.261 & -0.115 & 0.014 & 0.143 \\
$\Delta_{n}:$ Labor input growth & -0.004 & 0.221 & -0.065 & 0.000 & 0.061 \\
$\Delta_{m}:$ Materials input growth & 0.004 & 0.329 & -0.152 & 0.010 & 0.165 \\
$\Delta_{k}:$ Capital input growth & -0.045 & 0.417 & -0.220 & -0.078 & 0.051 \\
$\alpha_{n}:$ Share of labor costs & 0.307 & 0.172 & 0.184 & 0.280 & 0.393 \\
$\alpha_{m}:$ Share of materials & 0.584 & 0.182 & 0.484 & 0.606 & 0.714 \\
$1-\alpha_{n}-\alpha_{m}:$ Share of capital & 0.109 & 0.082 & 0.051 & 0.090 & 0.145 \\
Solow Residual (SR) & 0.015 & 0.159 & -0.057 & 0.009 & 0.079 \\
\hline
\end{tabular}

Notes: The sampling period goes from 2006 to 2012. The number of observations is 127869 . The variables $\Delta_{q}, \Delta_{n}, \Delta_{m}$, and $\Delta_{k}$ represent the annual growth rates of output, labor, materials, and capital, respectively, in the sampling period. The variables $\alpha_{n}, \alpha_{m}$ and $\alpha_{k}=1-\alpha_{n}-\alpha_{m}$ are the shares of labor, materials, and capital averaged over adjacent periods. The Solow residual is calculated as follows: $\mathrm{SR}=\Delta_{q}-\alpha_{n} \Delta_{n}-\alpha_{m} \Delta_{m}-\left(1-\alpha_{n}-\alpha_{m}\right) \Delta_{k} . Q_{1}$ and $Q_{3}$ correspond to the first and third quartiles and $Q_{2}$ corresponds to the median.

Then, in the second part of this study, we merge the estimated firm labor supply elasticity and firm total factor productivity with a matched employer-employee-job title dataset known as Quadros de Pessoal (Personnel Records). This dataset was created by the Portuguese Ministry of Employment and is an annual mandatory em- 
ployment survey addressed to establishments with at least one wage earner. Data is available from 1986 to 2012 for each wage earner, with the exception of workers of the Public Administration sector and domestic servants.

Detailed data are available on the establishment (location, economic activity, and employment), the firm (location, economic activity, employment, sales, year of formation, and legal framework), and for each and every of its workers (gender, age, education, occupation, earnings - base wage, seniority-related earnings, other regular and irregular benefits, and overtime pay, normal and overtime hours, and tenure $)^{3}$.

To estimate a Mincerian wage equation we considered a subset of these variables and some restrictions were imposed in the dataset. We restricted the analysis to fulltime workers, who were aged between 18 and 65 years old, and who earn a nominal wage of at least 80 percent of the mandatory minimum wage. Also, we excluded from the analysis workers from the agriculture and fishery sectors. Finally, we dropped around two percent of the observations that did not belong to the largest connected set. The dependent variable considered in the estimation is the natural logarithm of the real hourly wage.

\section{Product and labor market imperfections parameter}

The baseline model formulated to derive the product and labor market imperfection parameters is presented in equation (16). We directly estimate from the production function the labor and material output elasticities to derive the joint imperfections parameter as the difference between the output elasticity-revenue share ratio for labor and materials. The sign and significance of this parameter will determine which regime applies. Dobbelaere and Mairesse (2011) use the Swamy (1970) methodology and document considerable within-regime firm differences in the estimated product and labor markets imperfection parameters.

We believe production function estimates differ across firms due to firms' idiosyncratic heterogeneity and heterogeneity in the product and labor markets they operate in. Hence, in this study we resort to an empirical methodology that allows to derive a distribution of the labor and product markets imperfection parameters through the

\footnotetext{
${ }^{3}$ For a more detailed description of the dataset Quadros de Pessoal see Torres, Portugal, Addison, and Guimarães (2012), for example.
} 
estimation of 5-digit sector specific factor elasticities. The estimation uses the high dimensional fixed effects procedure developed by Portugal and Guimarães (2010) to compute the elasticity of output with respect to labor, materials, and capital through the estimation of a linear regression model with one interacted high dimensional fixed effect. The high dimensional fixed effect considered in the analysis is the 5-digit classification of economic activities. This level of disaggregation of the economic activity make us believe that we are close to the firm definition. This way we are able to draw a distribution of the 5-digit sector estimated output elasticities of labor, materials and capital as directly estimated from the production function. Then, we can obtain an estimate for the firm specific joint market imperfections parameter and derive firm specific estimates of the price-cost mark-up and labor market imperfection parameters. The baseline empirical specification to be estimated considers constant returns to scale ${ }^{4}\left(\lambda_{f t}=1\right)$ and is given by:

$$
q_{f t}-k_{f t}=\left(\varepsilon_{N}\right)_{s}\left[n_{f t}-k_{f t}\right]+\left(\varepsilon_{M}\right)_{s}\left[m_{f t}-k_{f t}\right]+\theta_{f t}
$$

Hence, the output elasticity for capital is given by $\left(\varepsilon_{K}\right)_{s}=1-\left(\varepsilon_{N}\right)_{s}-\left(\varepsilon_{M}\right)_{s}$.

The distribution of the estimates for the elasticities of labor, materials and capital with respect to output obtained through the estimation of the production function presented in equation (23) are shown in Figure 1. These figures show considerable dispersion in the estimated output elasticities.

These firm-level estimates are then considered to calculate a distribution of the joint market imperfections parameter ${ }^{5}$. The results are depicted in Figure 2. This figure shows that a considerable number of firms in the sample is characterized by an efficient bargaining model $\left(\widehat{\psi}_{f}>0\right)$ while another considerable part is classified as a monopsony $\left(\widehat{\psi}_{f}<0\right)$. In the first case, workers are assumed to receive a wage which exceeds their marginal revenue while in the second case workers receive a wage which is less than their marginal revenue ${ }^{6}$.

\footnotetext{
${ }^{4}$ The estimation results should be robust to this assumption once the first order conditions do not depend on the elasticity of scale parameter.

${ }^{5} \widehat{\psi}_{f}=\frac{\left(\widehat{\varepsilon}_{M}\right)_{s}}{\left(\bar{\alpha}_{M}\right)_{f}}-\frac{\left(\widehat{\varepsilon}_{N}\right)_{s}}{\left(\bar{\alpha}_{N}\right)_{f}}$, where $\left(\widehat{\varepsilon}_{M}\right)_{s}$ and $\left(\widehat{\varepsilon}_{N}\right)_{s}$ are the 5 -digit sector specific output elasticities of materials and labor, respectively, estimated from the production function, and $\left(\bar{\alpha}_{N}\right)_{f}$ and $\left(\bar{\alpha}_{M}\right)_{f}$ are the firm time-averaged shares of labor costs and intermediate consumption in total revenue.

${ }^{6}$ The case $\widehat{\psi}_{f}=0$ corresponds to the right to manage model (see Dobbelaere and Mairesse (2011) for details).
} 

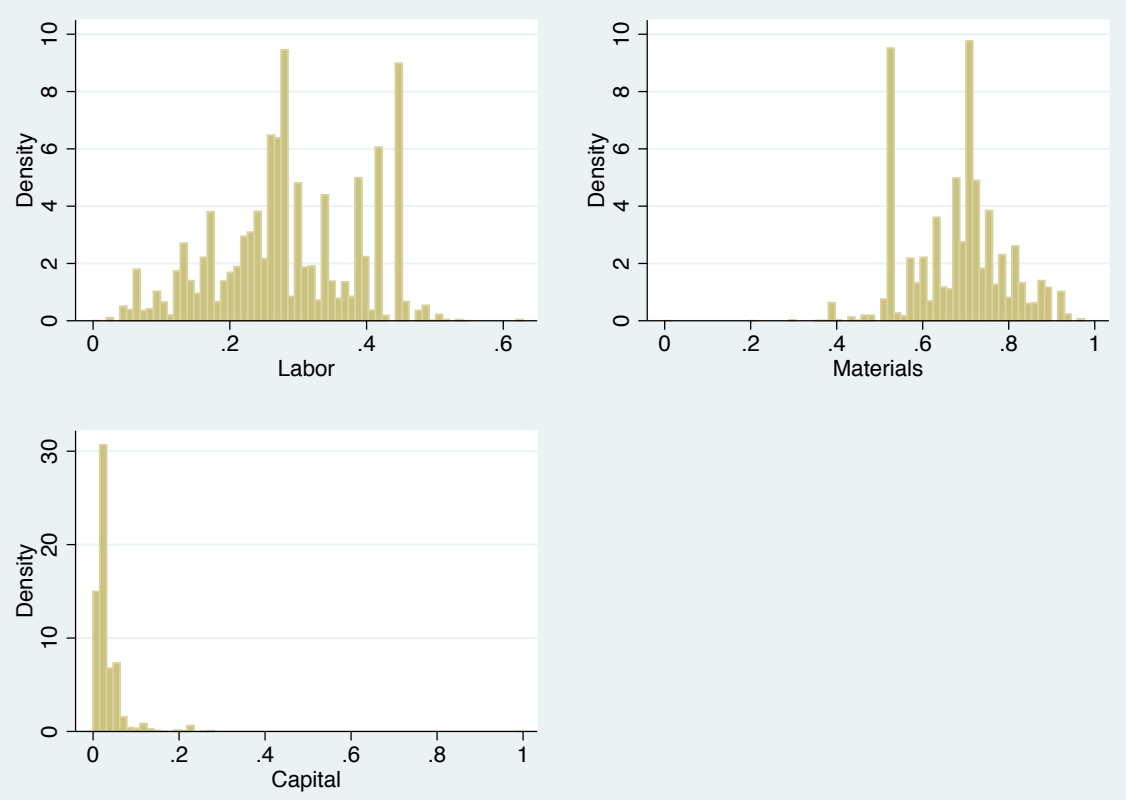

Figure 1 - Distribution of 5-digit sector estimated elasticities of labor, materials, and capital with respect to output weighted by the firm average number of employees.

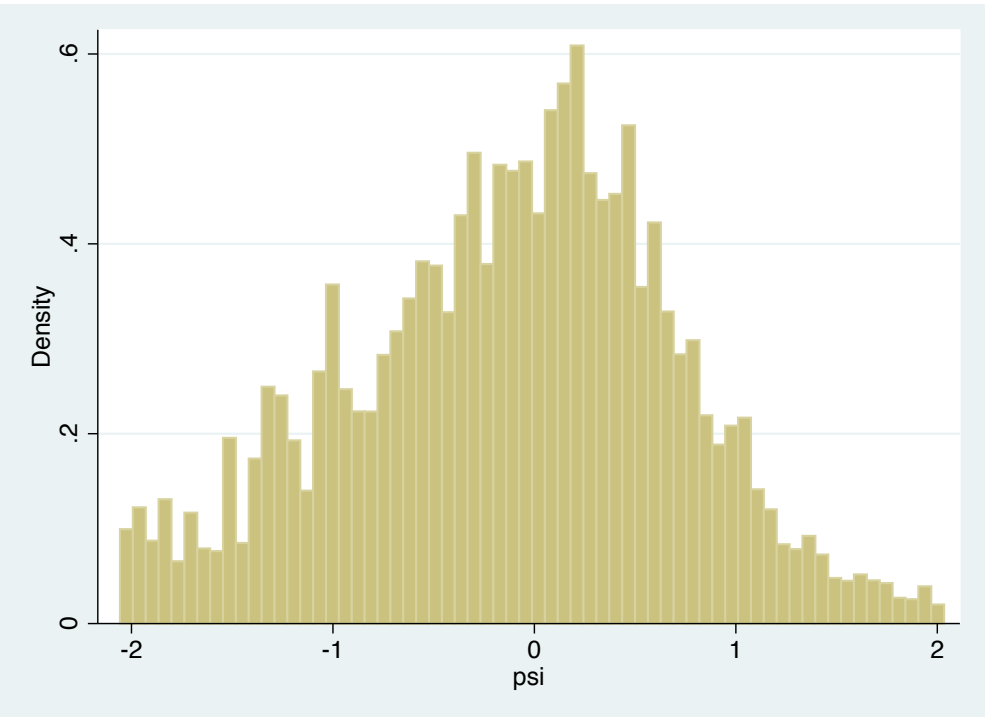

Figure 2 - Distribution of firm estimated joint market imperfections parameter $\left(\widehat{\psi}_{f}\right)$ weighted by the firm average number of employees. 
Once the regime is identified we can compute the product and labor market imperfections parameters as measured by the firm price-cost mark-up and rent-sharing or monopsony power, respectively. The empirical distribution of the estimated firm price-cost mark-up ${ }^{7}$ is shown in Figure 3 and suggest that a great number of firms operate in an imperfect competitive product market. Therefore, the estimates suggest that firms possess a considerable degree of market power in the product market.

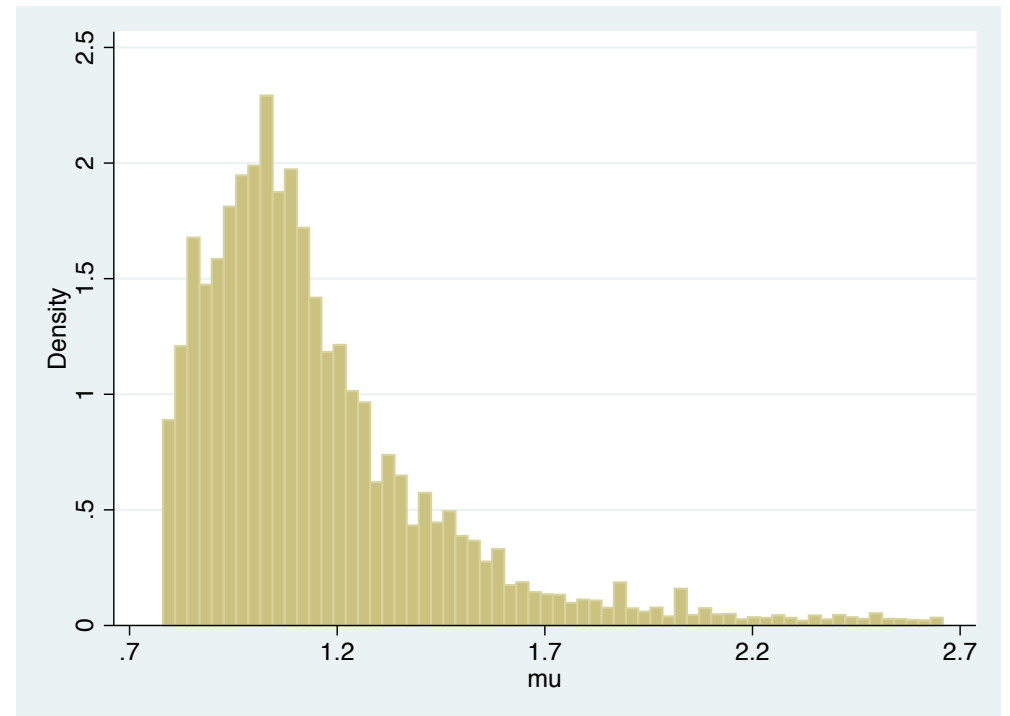

Figure 3 - Distribution of firm estimated price-cost mark-up $\left(\widehat{\mu}_{f}\right)$ weighted by the firm average number of employees.

In this study we focus the analysis on firms that possess some degree of monopsony power $\left(\widehat{\psi}_{f}<0\right)$ and explore the distribution of the estimated labor supply elasticity to a particular firm. The results for the firm labor supply elasticity $\widehat{\beta}_{f}^{8}$ and $\left(\widehat{\varepsilon}_{w}\right)_{f}=\frac{\widehat{\beta}_{f}}{1+\widehat{\beta}_{f}}$ are shown in Figure 4. We find evidence for imperfect competition in the labor market with considerable dispersion in the estimated labor supply elasticity across firms even within the same labor market. The empirical distributions of the absolute and relative extent of rent-sharing $\left(\widehat{\phi}_{f}\right.$ and $\widehat{\gamma}_{f}$, respectively) calculated for firms in the efficient bargaining setting $(\widehat{\psi}<0)$ are depicted in Figure 5. The results show considerable dispersion in the extent of rent-sharing within the efficient bargaining setting. The main descriptive statistics of the estimated parameters are reported in Table 2.

\footnotetext{
${ }^{7} \widehat{\mu}_{f}=\frac{\left(\widehat{\varepsilon}_{M}\right)_{s}}{\left(\bar{\alpha}_{M}\right)_{f}}$.

$8 \widehat{\beta}_{f}=\frac{\left(\bar{\alpha}_{N}\right)_{f}}{\left(\bar{\alpha}_{M}\right)_{f}} \frac{\left(\widehat{\varepsilon}_{M}\right)_{s}}{\left(\widehat{\varepsilon}_{N}\right)_{s}}$.
} 


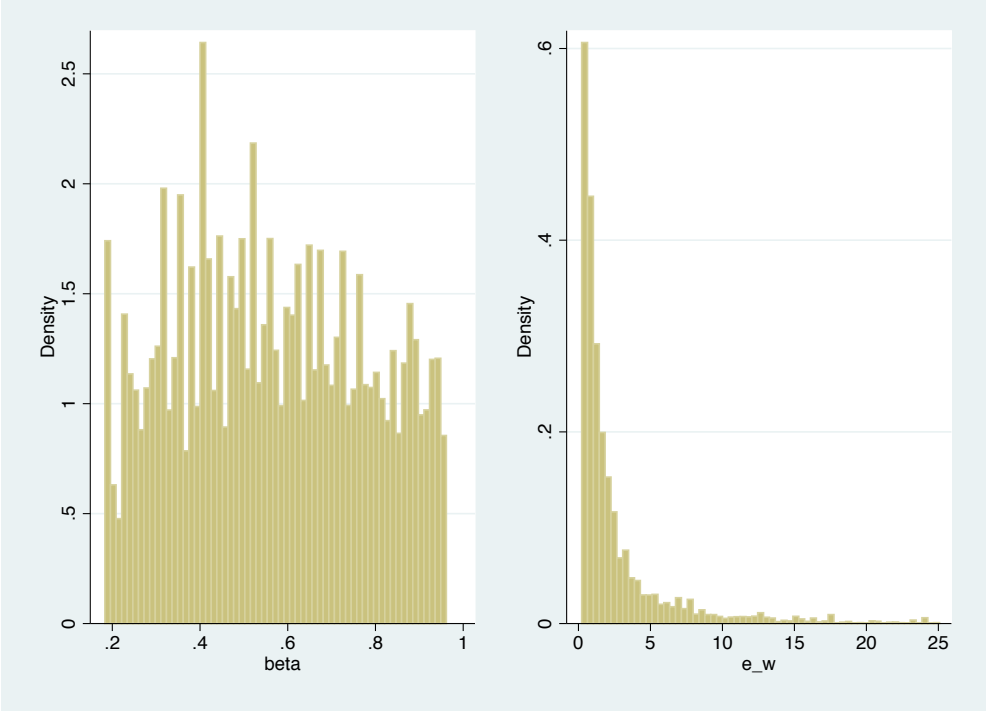

Figure 4 - Distribution of firm estimated elasticity of labor supply $\left(\widehat{\beta}_{f}\right.$ and $\left.\left(\widehat{\varepsilon}_{w}\right)_{f}\right)$ weighted by the firm average number of employees.

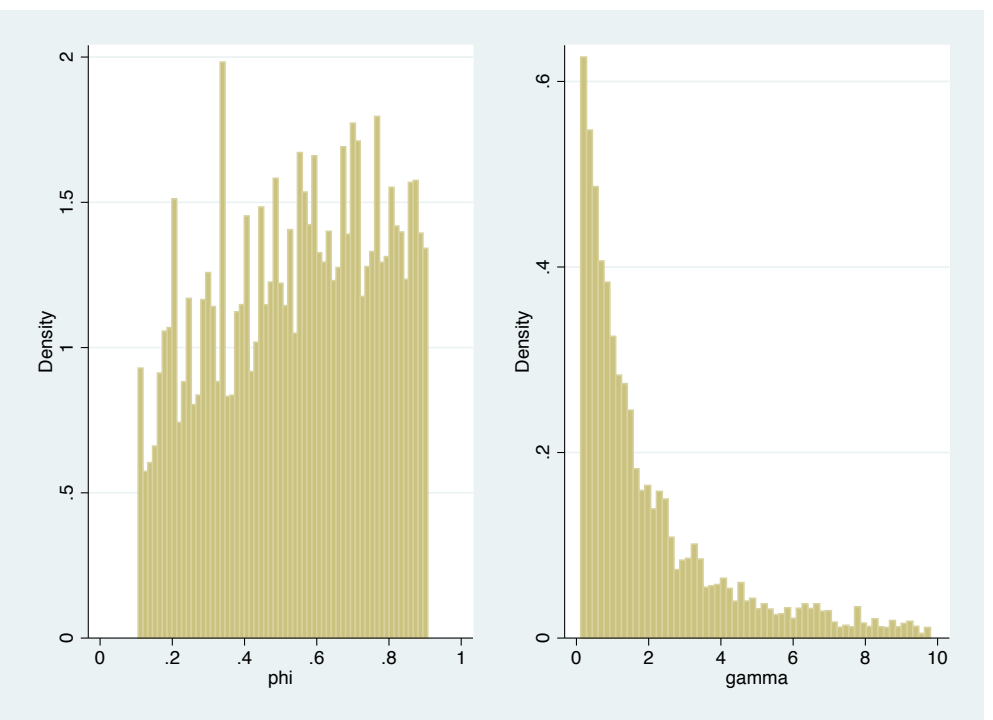

Figure 5 - Distribution of firm estimated absolute $\left(\widehat{\phi}_{f}\right)$ and relative $\left(\widehat{\gamma}_{f}\right)$ extent of rentsharing weighted by the firm average number of employees. 
Table 2 - Main summary statistics: Labor and product markets imperfections parameters

\begin{tabular}{lccccc}
\hline & \multicolumn{5}{c}{$2006-2012$} \\
\cline { 2 - 6 } & Mean & St.Dev. & $Q_{1}$ & $Q_{2}$ & $Q_{3}$ \\
\hline Joint markets imperfections parameter $(\widehat{\psi})$ & 0.091 & 0.769 & -0.357 & 0.157 & 0.597 \\
Price-cost mark-up $(\widehat{\mu})$ & 1.226 & 0.330 & 1.002 & 1.146 & 1.359 \\
Wage elasticity of labor supply $\left(\widehat{\varepsilon}_{w}\right)$ & 3.271 & 4.228 & 0.767 & 1.624 & 3.824 \\
Relative extent of rent-sharing $(\widehat{\gamma})$ & 2.166 & 2.057 & 0.666 & 1.433 & 2.981 \\
\hline
\end{tabular}

Notes: The sampling period goes from 2006 to 2012. $Q_{1}$ and $Q_{3}$ correspond to the first and third quartiles and $Q_{2}$ corresponds to the median. The descriptive statistics of the joint markets imperfections parameter and the price-cost mark-up are based on 109812 observations. The efficient bargaining and the monopsony parameters are based on 63539 and 46620 observations, respectively.

These results show that some firms possess a considerable degree of product and labor market power and confirm that the hypothesis of perfectly competitive product and labor markets is not suitable to characterize these markets.

\section{Total factor productivity}

The total factor productivity (TFP) is estimated through the following equation:

$$
\mathcal{Q}_{f t}=\varepsilon_{N} N_{f t}+\varepsilon_{M} M_{f t}+\varepsilon_{K} K_{f t}+\eta_{f}+\nu_{s t}+u_{f t}
$$

where $\eta_{f}$ accounts for time-invariant observed and unobserved firm heterogeneity, $\nu_{s t}$ is a 5-digit sector $s$ specific time trend that allows to control for sector specific productivity shocks, and $u_{i t}$ is a residual component. Therefore, firm-level TFP is given by $\Theta_{f t}=A \exp \left(\eta_{f}+\nu_{s t}+u_{f t}\right)$. The results of the high-dimensional fixed effects estimation (see Portugal and Guimarães (2010) for details on the estimation procedure) are reported in Table $3^{9}$. Figure 6 depicts the distribution of firm TFP

\footnotetext{
${ }^{9}$ We also estimate this model using the two semi-parametric approaches proposed by Olley and Pakes (1996) and Levinsohn and Petrin (1999). The first uses the firm's investment decision to proxy
} 
weighted by the number of employees. Our results are in line with the previous literature showing considerable variation in the productivity of Portuguese firms, with a large number of firms being relatively low productive and a small number of firms being more productive.

Table 3 - Estimation results: Total factor productivity

\begin{tabular}{lcc}
\hline & Coef. & Std. Error \\
\hline Materials & 0.6222 & 0.0004 \\
Labor & 0.2229 & 0.0003 \\
Capital & 0.0184 & 0.0002 \\
\hline Observations & \multicolumn{2}{c}{127869} \\
$R^{2}$ & \multicolumn{2}{c}{0.996} \\
\hline
\end{tabular}

Notes: The sampling period goes from 2006 to 2012. The dependent variable is the (natural logarithm of) sales. Materials refers to firm's intermediate consumption, labor is measured by the average number of employees, and capital is the net book value of the tangible assets. Linear regression estimation with two high dimensional fixed effects: firm fixed effects and time fixed effects interacted with 5-digit sector dummies.

\section{$6 \quad$ Wage regressions}

Over the last decades, empirical evidence suggests the presence of considerable variability on wages (Abowd, Finer, and Kramarz (1999), Abowd, Kramarz, and Margolis (1999) and Cardoso, Guimarães, and Portugal (2016)). Researchers have estimated wage regressions incorporating both worker effects and firm effects with the goal of disentangling the effects of worker decisions and firm wage policies in wage formation. More recently, Torres, Portugal, Addison, and Guimarães (2012) use Portuguese longitudinal matched employer-employee data to estimate a wage regression and add job title heterogeneity as an important third dimension of wage formation. In fact, the characteristics of some tasks (namely, the risk of fatal or serious accidents, the

for the unobserved time-varying productivity shock to account for the problem of simultaneity, and considers survival probabilities to address the problem of selectivity. The second is similar but uses the intermediate inputs to proxy for unobservable variables. The results are very similar to the ones obtained through the high dimensional fixed effects estimation with firm fixed effects and year fixed effects interacted with 5-digit sector dummies. 


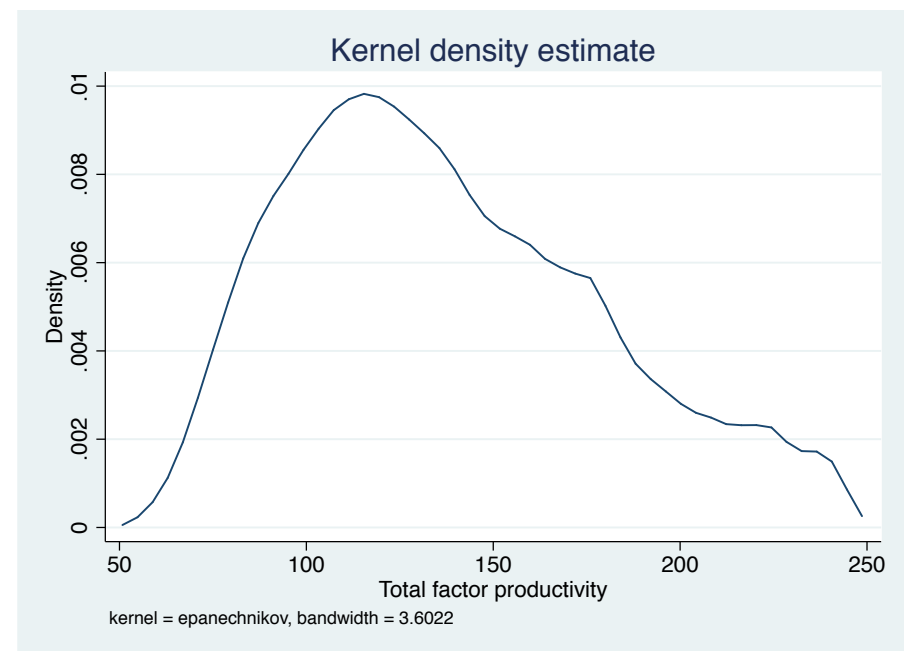

Figure 6 - Distribution of firm TFP weighted by the firm average number of employees.

workplace conditions in which the tasks are performed, the specific training or skills that some tasks require) contribute for wage differentiation. The wage decomposition shows that in Portugal, firm, worker and job title time-invariant heterogeneity accounts for a significant fraction of the total wage variation. The authors estimate that worker permanent heterogeneity is the primary source of wage variation accounting for approximately 36 per cent, followed by firm permanent effects that account for almost 29 per cent of the total wage variation. The job title permanent heterogeneity play a less significant but non-negligible role explaining close to 10 per cent of wage variation.

The presence of frictions in the labor market may explain why wages vary across labor markets and even across firms within a given labor market. In this section we explore the importance of the firm specific degree of monopsony power and firm total factor productivity in explaining wage formation. Furthermore, we also study the contribution of rent-sharing for wage formation. We pick the estimates of the labor supply elasticity and relative extent of rent-sharing as obtained in section 4, and combine these with firm-level productivity as calculated in section 5 .

Next we present the methodology applied in this study to understand the importance of monopsony power, relative extent of rent-sharing, and total factor productivity in explaining the firm wage setting policy. First, we follow Torres, Portugal, Addison, and Guimarães (2012) and estimate a standard Mincerian wage equation 
with the inclusion of three high-dimensional fixed effects to account for firm, worker, and job-title time-invariant observed and unobserved heterogeneity:

$$
\ln w_{i f j t}=\mathbf{X}_{i f t} \beta+\phi_{i}+\gamma_{f}+\omega_{j}+\tau_{t}+\epsilon_{i f j t}
$$

where the dependent variable $\ln w_{i f j t}$ is the natural logarithm of the real hourly wage of worker $i(i=1, \ldots, N)$ working at firm $f(f=1, \ldots, F)$ with the job title $j(j=1, \ldots, J)$ in year $t(t=1, \ldots, T)$. The vector $\mathbf{X}_{i f t}$ is a row-vector of $k$ observed characteristics of the worker $i$ and firm $f$ (and includes the quadratic terms on age and tenure within the firm and the worker qualifications). The term $\phi_{i}$ is a worker fixed effect, $\gamma_{f}$ is a firm fixed effect, $\omega_{j}$ is a job fixed effect, and $\tau_{t}$ is a set of year dummies. The disturbance term $\epsilon_{i f j t}$ has the conventional properties.

This equation is estimated using the Quadros de Pessoal matched employer-employee data for the period comprised between 1986 and 2012 and applying the iterative algorithm developed by Portugal and Guimarães (2010) that produces the exact solution of the least squares estimation of equations with three high dimensional fixed effects. From the estimation of this equation we obtain the estimated firm $\widehat{\gamma}_{f}$, worker $\widehat{\phi}_{i}$, and job title $\widehat{\omega}_{j}$ fixed effects which represent firm, worker and job title time-invariant observed and unobserved heterogeneity, respectively.

Then, we combine the estimates of the labor supply elasticities and total factor productivity computed in the previous sections with the Quadros de Pessoal dataset ${ }^{10}$. We proceed by applying the Gelbach's exact decomposition (Gelbach (2014)) to quantify the importance of the firm monopsony power and total factor productivity to explain total wage variation ${ }^{11}$.

The base specification is given by:

$$
\ln w_{i f t}=\alpha_{0}+\alpha_{1} \widehat{L M I}_{f t}+\alpha_{2} \widehat{\Theta}_{f t}+\mathbf{X}_{i f t} \xi+\tau_{t}+\vartheta_{i t}
$$

where the dependent variable is the natural logarithm of the real hourly wage $\left(\ln w_{i t}\right)$ and the explanatory variables are the estimated labor market imperfection $\left(\widehat{L M I}_{f t}\right)$

\footnotetext{
${ }^{10}$ We end with a four-dimensional panel data (firm, worker, job-title, and year dimensions) spanning from 2006 to 2012, since the labor market imperfection parameters and the total factor productivity are estimated using the IES information which is only available for this period.

${ }^{11} \mathrm{~A}$ more detailed presentation of the Gelbach's decomposition can be found in section A.
} 
parameter which is the firm's monopsony power $\left(1 /\left(\widehat{\varepsilon}_{w}\right)_{f}\right)$ in the case of monopsonist firms and the relative extent of rent-sharing $\left(\widehat{\gamma}_{f t}\right)$ in the case of firms in the efficient bargaining setting, the estimated firm total factor productivity $\left(\widehat{\Theta}_{f t}\right)$, and a vector of explanatory variables $\mathbf{X}_{i f t}$ (quadratic terms on age and tenure, worker qualifications, and worker gender). The term $\tau_{t}$ is a vector of year dummies and $\vartheta_{i t}$ is a disturbance term with the conventional properties.

In turn, the full specification is given by the following equation:

$$
\ln w_{i f j t}=a_{0}+a_{1} \times \widehat{L M I}_{f t}+a_{2} \widehat{\Theta}_{f t}+\mathbf{X}_{i f t} \beta+\widehat{\phi}_{i}+\widehat{\gamma}_{f}+\widehat{\omega}_{j}+\tau_{t}+\epsilon_{i f j t}
$$

where $\widehat{\phi}_{i}, \widehat{\gamma}_{f}$, and $\widehat{\omega}_{j}$ are the estimated worker, firm, and job-title time-invariant heterogeneity.

\section{$7 \quad$ Estimation results}

\subsection{Monopsony}

The estimation results of equation (26) are reported in columns (1) and (2) of Table 4. According to these estimates, the elasticity of labor supply is positively and significantly associated with wages. Since the elasticity of labor supply is inversely related to monopsony power, this means that firms with more market power manage to pay lower wages to their workers. The estimates presented in column (2) suggest that a one standard deviation increase in firm's monopsony power contributes to decrease earnings of workers by approximately 2 percent, ceteris paribus. Also, we find that more productive firms pay on average higher wages, holding everything else constant. It is interesting to notice that the elasticity of labor supply to the firm and the firm total factor productivity alone explain a considerable fraction of the variation in the earnings of its workers (approximately 39 percent).

To shed further light on the importance of market power and productivity to explain the wage policy of the firm as measured by the firm time-invariant heterogeneity we proceed with the Gelbach's decomposition. The estimation results of the full model (presented in equation (27)) are reported in column (3) of Table 4. Then, in columns 
Table 4 - Monopsony power and total factor productivity

\begin{tabular}{|c|c|c|c|}
\hline & $\begin{array}{c}(1) \\
\ln w_{i f j t}\end{array}$ & $\begin{array}{c}(2) \\
\ln w_{i f j t}\end{array}$ & $\begin{array}{c}(3) \\
\ln w_{i f j t}\end{array}$ \\
\hline Monopsony power $\left(1 /\left(\widehat{\varepsilon}_{w}\right)_{f}\right)$ & $\begin{array}{c}-0.0234^{* * *} \\
(0.0003)\end{array}$ & $\begin{array}{c}-0.0108^{* * *} \\
(0.0002)\end{array}$ & $\begin{array}{c}-0.0002^{* *} \\
(0.0001)\end{array}$ \\
\hline Total factor productivity $\left(\widehat{\theta}_{f t}\right)$ & $\begin{array}{c}0.5411^{* * *} \\
(0.0010)\end{array}$ & $\begin{array}{c}0.4075^{* * *} \\
(0.0010)\end{array}$ & $\begin{array}{c}0.0039^{* * *} \\
(0.0008)\end{array}$ \\
\hline Age & & $\begin{array}{c}0.0290^{* * *} \\
(0.0002)\end{array}$ & $\begin{array}{c}0.0199^{* * *} \\
(0.0001)\end{array}$ \\
\hline $\mathrm{Age}^{2}$ & & $\begin{array}{c}-0.0002^{* * *} \\
(0.0000)\end{array}$ & $\begin{array}{c}-0.0002^{* * *} \\
(0.0000)\end{array}$ \\
\hline Tenure & & $\begin{array}{c}0.0158^{* * *} \\
(0.0001)\end{array}$ & $\begin{array}{c}0.0081^{* * *} \\
(0.0001)\end{array}$ \\
\hline Tenure $^{2}$ & & $\begin{array}{c}-0.0003^{* * *} \\
(0.0000)\end{array}$ & $\begin{array}{c}-0.0002^{* * *} \\
(0.0000)\end{array}$ \\
\hline Gender & & $\begin{array}{c}-0.2607^{* * *} \\
(0.0007)\end{array}$ & \\
\hline Constant & $\begin{array}{c}-2.4622^{* * *} \\
(0.0058)\end{array}$ & $\begin{array}{c}-2.4366^{* * *} \\
(0.0069)\end{array}$ & $\begin{array}{c}0.1232^{* * *} \\
(0.0047)\end{array}$ \\
\hline Fixed effects & No & No & Yes \\
\hline Observations & 1022391 & 1022391 & 1022391 \\
\hline Adjusted $R^{2}$ & 0.391 & 0.546 & 0.889 \\
\hline
\end{tabular}

Notes: The dependent variable is the natural logarithm of real hourly wage $\left(\ln w_{i f j t}\right)$. The sampling period goes from 2006 to 2012. All specifications include year dummies and dummy variables for education levels. Ordinary Least Squares (OLS) estimation with bootstrap standard errors (using 1000 draws) in parentheses. ${ }^{*} p<0.1,{ }^{* *} p<0.05,{ }^{* * *} p<0.01$. 
(1), (2), and (3) of Table 5 we find the decomposition of the wage differential given by the difference between the estimates of the base and full models reported in columns (2) and (3) of Table 4, respectively. The results suggest that, in fact, monopsony power is mostly related to the firm permanent heterogeneity. This evidences the role of monopsony power and firm's total factor productivity to explain heterogeneity in wage formation, even after controlling for detailed firm, worker and job title characteristics. This is in line with the suggestion of Goux and Maurin (1999) and Abowd, Finer, and Kramarz (1999) that the presence of firm effects in wage regressions, after controlling for person and industry characteristics, is strongly suggestive of market power. The coefficients of firm's monopsony power and firm's productivity converge to zero in the case of the worker and job title permanent heterogeneity ${ }^{12}$.

Table 5 - Gelbach decomposition

\begin{tabular}{lccc}
\hline & $(1)$ & $(2)$ & $(3)$ \\
& $\widehat{\gamma}_{f}$ & $\widehat{\phi}_{i}$ & $\widehat{\omega}_{j}$ \\
\hline Monopsony power $\left(1 /\left(\widehat{\varepsilon}_{w}\right)_{f}\right)$ & $-0.0112^{* * *}$ & $0.0015^{* * *}$ & $-0.0009^{* * *}$ \\
& $(0.0001)$ & $(0.0001)$ & $(0.0001)$ \\
Total factor productivity $\left(\widehat{\theta}_{f t}\right)$ & $0.3886^{* * *}$ & $0.0173^{* * *}$ & $-0.0023^{* * *}$ \\
& $(0.0004)$ & $(0.0006)$ & $(0.0003)$ \\
\hline Observations & 1022391 & 1022391 & 1022391 \\
Adjusted $R^{2}$ & 0.593 & 0.376 & 0.359 \\
\hline
\end{tabular}

Notes: The dependent variable is the firm, worker, and job title time-invariant heterogeneity in columns (1), (2), and (3), respectively. The sampling period goes from 2006 to 2012. All specifications include year dummies and dummy variables for education levels. Ordinary Least Squares (OLS) estimation with bootstrap standard errors (using 1000 draws) in parentheses. ${ }^{*} p<0.1,{ }^{* *} p<0.05,{ }^{* * *} p<0.01$.

\subsection{Efficient bargaining}

The contributions of the relative extent of rent-sharing parameter and total factor productivity to explain wage formation are presented in Table 6. The estimates related

\footnotetext{
${ }^{12}$ These results are robust to using different criteria to characterize firms according to the labor market setting, namely using a statistical significance criterion.
} 
to the role of total factor productivity in explaining wages are consistent with the ones obtained in the previous section and show that total factor productivity is a crucial determinant of wage heterogeneity.

Table 6 - Efficient bargaining and total factor productivity

\begin{tabular}{|c|c|c|c|}
\hline & $\begin{array}{c}(1) \\
\ln w_{i f j t}\end{array}$ & $\begin{array}{c}(2) \\
\ln w_{i f j t}\end{array}$ & $\begin{array}{c}(3) \\
\ln w_{i f j t}\end{array}$ \\
\hline Relative extent of rent-sharing $\left(\widehat{\gamma}_{f t}\right)$ & $\begin{array}{c}-0.0279^{* * *} \\
(0.0002)\end{array}$ & $\begin{array}{c}-0.0130^{* * *} \\
(0.0002)\end{array}$ & $\begin{array}{c}-0.0007^{* * *} \\
(0.0001)\end{array}$ \\
\hline Total factor productivity $\left(\widehat{\theta}_{f t}\right)$ & $\begin{array}{c}0.5343^{* * *} \\
(0.0013)\end{array}$ & $\begin{array}{c}0.4460^{* * *} \\
(0.0011)\end{array}$ & $\begin{array}{c}0.0097^{* * *} \\
(0.0008)\end{array}$ \\
\hline Age & & $\begin{array}{c}0.0265^{* * *} \\
(0.0003)\end{array}$ & $\begin{array}{c}0.0192^{* * *} \\
(0.0001)\end{array}$ \\
\hline $\mathrm{Age}^{2}$ & & $\begin{array}{c}-0.0002^{* * *} \\
(0.0000)\end{array}$ & $\begin{array}{c}-0.0002^{* * *} \\
(0.0000)\end{array}$ \\
\hline Tenure & & $\begin{array}{c}0.0162^{* * *} \\
(0.0001)\end{array}$ & $\begin{array}{c}0.0077^{* * *} \\
(0.0001)\end{array}$ \\
\hline Tenure $^{2}$ & & $\begin{array}{c}-0.0003^{* * *} \\
(0.0000)\end{array}$ & $\begin{array}{c}-0.0002^{* * *} \\
(0.0000)\end{array}$ \\
\hline Gender & & $\begin{array}{c}-0.2787^{* * *} \\
(0.0008)\end{array}$ & \\
\hline Constant & $\begin{array}{c}-2.3529^{* * *} \\
(0.0069)\end{array}$ & $\begin{array}{c}-2.4728^{* * *} \\
(0.0076)\end{array}$ & $\begin{array}{c}0.1180^{* * *} \\
(0.0047)\end{array}$ \\
\hline Fixed effects & No & No & Yes \\
\hline Observations & 838563 & 838563 & 838563 \\
\hline Adjusted $R^{2}$ & 0.382 & 0.542 & 0.884 \\
\hline
\end{tabular}

Notes: The dependent variable is the natural logarithm of real hourly wage $\left(\ln w_{\text {ifjt }}\right)$. The sampling period goes from 2006 to 2012. All specifications include year dummies and dummy variables for education levels. Ordinary Least Squares (OLS) estimation with bootstrap standard errors (using 1000 draws) in parentheses. ${ }^{*} p<0.1,{ }^{* *} p<0.05,{ }^{* * *} p<0.01$.

Based on the standard collective bargaining literature we would expect a positive correlation between the relative extent of rent-sharing parameter and wages. However, the estimation results suggest a negative impact of the relative extent of rent-sharing on wages and therefore workers with a larger share of the rents fail to get extra income. Instead, a larger share of the rents is estimated to depress the wages paid by the firm.

While not intuitive, this result is similar to the results presented in Dobbelaere and Mairesse (2011). The authors estimate the correlation between the relative extent 
of rent-sharing and firm size, capital intensity, among other firm variables, and also find a negative correlation between these variables.

\subsection{The gender pay gap}

Monopsonistic competition may help to explain one of the stylised empirical results in the labor economics literature which is the gender pay gap. Ransom and Oaxaca (2010) and Hirsch, Shank, and Schnabel (2010) investigate women's and men's labor supply to the firm separately using a dynamic model of monopsony and find that women have lower elasticities than men. The reasons for this result may be different preferences over nonwage job characteristics (namely, hours of work and job location) and a higher degree of worker immobility. Monopsonist employers may take advantage of this lower female elasticity of labor supply to the firm and pay lower wages to women, ceteris paribus. Hirsch, Shank, and Schnabel (2010) suggests that this result implies that at least one-third of the gender pay gap might be wage discrimination by monopsonist employers ${ }^{13}$.

These differences in the labor supply elasticity between women and men suggest that it is likely that the marginal impact of increasing the elasticity of labor supply at the firm level may differ considerably across these two groups. Since in our model monopsony power is inversely related to the labor supply elasticity at the firm level, this means that the ability of monopsonist firms to mark down wages is higher in the case of female workers. In fact, in our sample, the average estimated labor supply elasticity for female and male workers is approximately 1.95 and 2.316, respectively. This means that firms hiring a large fraction of male workers have on average less monopsony power.

Table 7 presents the results of the estimation of equation (26) separately for male and female workers. These results make clear that the marginal impact of increasing the labor supply elasticity to a particular firm is much lower for female workers and that there are considerable differences on how market power on the firms' side affects workers' wages.

\footnotetext{
${ }^{13}$ This explanation aligns with the Robinsonian monopsony model of wage discrimination (?).
} 
Table 7 - Monopsony power and total factor productivity by gender

\begin{tabular}{|c|c|c|c|}
\hline & \multirow[b]{2}{*}{ All } & \multicolumn{2}{|c|}{ By gender } \\
\hline & & Male & Female \\
\hline \multirow{2}{*}{ Monopsony power $\left(1 /\left(\widehat{\varepsilon}_{w}\right)_{f}\right)$} & $-0.0108^{* * *}$ & $-0.0152^{* * *}$ & $-0.0058^{* * *}$ \\
\hline & $(0.0002)$ & $(0.0003)$ & $(0.0003)$ \\
\hline \multirow{2}{*}{ Total factor productivity $\left(\widehat{\theta}_{f t}\right)$} & $0.4075^{* * *}$ & $0.4190^{* * *}$ & $0.3834^{* * *}$ \\
\hline & $(0.0010)$ & $(0.0013)$ & $(0.0014)$ \\
\hline \multirow[t]{2}{*}{ Age } & $0.0290^{* * *}$ & $0.0349^{* * *}$ & $0.0201^{* * *}$ \\
\hline & $(0.0003)$ & $(0.0003)$ & $(0.0004)$ \\
\hline \multirow[t]{2}{*}{$\mathrm{Age}^{2}$} & $-0.0002^{* * *}$ & $-0.0003^{* * *}$ & $-0.0001^{* * *}$ \\
\hline & $(0.0000)$ & $(0.0000)$ & $(0.0000)$ \\
\hline \multirow[t]{2}{*}{ Tenure } & $0.0158^{* * *}$ & $0.0174^{* * *}$ & $0.0127^{* * *}$ \\
\hline & $(0.0001)$ & $(0.0002)$ & $(0.0002)$ \\
\hline \multirow[t]{2}{*}{ Tenure $^{2}$} & $-0.0003^{* * *}$ & $-0.0003^{* * *}$ & $-0.0002^{* * *}$ \\
\hline & $(0.0000)$ & $(0.0000)$ & $(0.0000)$ \\
\hline \multirow[t]{2}{*}{ Gender } & $-0.2607^{* * *}$ & & \\
\hline & $(0.0007)$ & & \\
\hline \multirow[t]{2}{*}{ Constant } & $-2.4366^{* * *}$ & $-2.9231^{* * *}$ & $-2.5561^{* * *}$ \\
\hline & $(0.0068)$ & $(0.0093)$ & $(0.0106)$ \\
\hline Fixed effects & No & No & No \\
\hline Observations & 1022391 & 616780 & 405611 \\
\hline Adjusted $R^{2}$ & 0.546 & 0.501 & 0.513 \\
\hline
\end{tabular}

Notes: The dependent variable is the natural logarithm of real hourly wage $\left(\ln w_{i f j t}\right)$. The sampling period goes from 2006 to 2012. All specifications include year dummies and dummy variables for education levels. Ordinary Least Squares (OLS) estimation with bootstrap standard errors (using 1000 draws) in parentheses. ${ }^{*} p<0.1,{ }^{* *} p<0.05,{ }^{* *} p<0.01$.

\section{Conclusions}

A central feature of perfectly competitive markets is that markets clear meaning that all workers with similar quality should be paid the same market clearing wage. Recent empirical evidence suggests the presence of considerable wage dispersion among 
workers with similar characteristics and among similar firms. A potential explanation for the presence of firm effects in wage regressions after accounting for detailed firm, worker, and job title heterogeneity rely on the presence of significant frictions in the labor market, namely asymmetric information, worker immobility, and heterogenous preferences, that may constitute sources of market power for employers.

In the new monopsony literature search frictions imply that firms may face an upward labor supply curve even if operating in a labor market with many competing firms.

In this study we use matched employer-employee data and firm balance sheet data to investigate the importance of firm total factor productivity and firm labor market power in explaining firm heterogeneity in wage formation. We use a linear regression model with one interacted high dimensional fixed effect to estimate 5-digit sector-specific elasticity of output with respect to input factors directly from the production function. This allows to derive firm specific price-cost mark-up and firm specific elasticity of labor supply. The results suggest that a considerable fraction of Portuguese firms are classified as monopsonist and a broad range of firm market power among monopsonist firms. The hypothesis that the elasticity of labor supply is finite has major implications for theoretical models of labor economics.

We proceed by investigating the impact of the elasticity of labor supply to a particular firm and firm total factor productivity on individuals' earnings. Furthermore, we use the Gelbach's exact decomposition to understand how firm's monopsony power is associated with the firm's wage setting policy. The results suggest that a one standard deviation increase in the labor supply elasticity increases wages by approximately 1.51 percent, ceteris paribus. This means that monopsony power affects negatively the wages of workers. Also, we find evidence that the elasticity of labor supply is mainly correlated with the firm effects as hypothesized in the labor economics literature. This suggests that firm market power is a key ingredient to explain heterogeneity in wage formation.

Lastly, we analyse if there are any gender differences on the impact of the labor supply elasticity on earnings. The results evidence that the marginal impact of increasing the labor supply elasticity to a particular firm is much lower for female workers and that there are considerable differences on how market power on the firms' side affect workers' wages. This finding is intimately related with the gender pay gap and sug- 
gests that we should consider firms' market power when analysing wage differentials arising from gender differences. 


\section{References}

Abowd, J. M., H. Finer, And F. Kramarz (1999): The creation and analysis of employer-employee matched datachap. Individual and firm heterogeneity in compensation: An analysis of matched longitudinal employer-employee data for the state of Washington, pp. 3-24. Amsterdam: North Holland.

Abowd, J. M., F. Kramarz, and D. N. Margolis (1999): "High wage workers and high wage firms," Econometrica, 67(2), 251-335.

Bhaskar, V., A. Manning, And T. To (2002): "Oligopsony and monopsonistic competition in labor markets," Journal of Economic Perspectives, 16(2), 155-74.

Boal, W. M., And M. R. Ransom (1997): "Monopsony in the labor market," Journal of Economic Literature, 35(1), 86-112.

Burdett, K., And D. Mortensen (1998): "Wage differentials, employer size, and unemployment," International Economic Review, 39(2), 257-73.

Cardoso, A. R., P. Guimarães, and P. Portugal (2016): "What drives the gender wage gap? A look at the role of firm and job title heterogeneity," Oxford Economic Papers, 68(2), 506-24.

Depew, B., And T. A. SøRensen (2013): "The elasticity of labor supply to the firm over the business cycle," Labour Economics, 24, 196-204.

Dobbelaere, S. (2004): "Estimation of price-cost margins and union bargaining power for Belgian manufacturing," International Journal of Industrial Organization, 22(10), 13811398.

Dobbelaere, S., And J. Mairesse (2011): "Panel data estimates of the production function and product and labor market imperfections," Journal of Applied Econometrics, $28,1-46$.

GelBach, J. B. (2014): "When do covariates matter? And which ones, and how much?," Journal of Labor Economics, Forthcoming.

Goux, D., And E. Maurin (1999): "Persistence in inter industry wage differentials: A reexamination using matched worker-firm panel data," Journal of Labor Economics, 17(3), $492-533$.

HALL, R. E. (1988): "The relationship between price and marginal cost in US industry," Journal of Political Economy, 96(5), 921-47.

Hirsch, B., T. Shank, And C. Schnabel (2010): "Differences in labor supply to monop- 
sonistic firms and the gender pay gap: an empirical analysis using linked employeremployee data from Germany," Journal of Labor Economics, 28, 291-330.

Levinsohn, J., And A. Petrin (1999): "When industries become more productive, do firms? Investigating productivity dynamics," NBER Workin Paper W6893.

Manning, A. (2003): Monopsony in motion: imperfect competition in labor markets. Princeton, NJ.

Olley, S. G., ANd A. Pakes (1996): "The dynamics of productivity in the telecommunications equipment industry," Econometrica, 64(6), 1293-97.

Portugal, P., And P. Guimarães (2010): "A simple feasible alternative procedure to estimate models with high-dimensional fixed effects," Stata Journal, 10(4), 628-49.

Ransom, M. R., And R. L. OAxaca (2010): "New market power models and sex differences in pay," Journal of Labor Economics, 28, 267-290.

SHIMER, R. (2005): "The assignment of workers to jobs in an economy with coordination frictions," Journal of Political Economics, 113(5), 996-1025.

Stevens, M. (1994): "A theoretical model of on-the-job training with imperfect competition," Oxford Economic Papers, 46, 537-62.

SwAmy, P. A. V. B. (1970): "Efficient inference in a random coefficient regression model," Econometrica, 38(2), 311-23.

Torres, S., P. Portugal, J. Addison, and P. Guimarães (2012): "The sources of wage variation: A three-way high dimensional fixed effects," mimeo.

Weber, D. A. (2013): "Firm market power and the earnings distribution," IZA DP No. 7342. 


\section{A Gelbach decomposition}

In this section we closely follow Cardoso, Guimarães, and Portugal (2016) to present the methodological details related to the Gelbach decomposition proposed by Gelbach (2014). The linear wage equation estimated is given by:

$$
\ln w_{i f j t}=\mathbf{X}_{i f t} \beta+\phi_{i}+\gamma_{f}+\omega_{j}+\tau_{t}+\epsilon_{i f j t}
$$

where $\ln w_{\text {ifjt }}$ is the natural logarithm of the real hourly wage of individual $i(\mathrm{i}=1, \ldots, \mathrm{N})$ working at firm $f(\mathrm{f}=1, \ldots, \mathrm{F})$ holding a job title $j(\mathrm{j}=1, \ldots, \mathrm{J})$ at year $t(\mathrm{t}=1, \ldots, \mathrm{T})$. The vector $X_{i f t}$ contains $k$ observed time-varying characteristics of individual $i$ (quadratic terms on age and yearly seniority within the firm). The terms $\phi_{i}, \gamma_{f}$, and $\omega_{j}$ represent the individual, firm, and job-title fixed effects, respectively, and measure observed and unobserved individual, firm, and job-title time-invariant heterogeneity. The term $\tau_{t}$ is a set of year dummies.

Consider the basic regression of the natural logarithm of hourly wages on the set of explanatory variables defined above and time dummies. This can be expressed in matrix notation as:

$$
\mathbf{Y}=\mathbf{X b}+\epsilon
$$

Then, following Gelbach (2014) and the omitted variable bias formula we can write the difference between the coefficients of the basic specification defined in equation (29) and those of the full specification presented in equation (28) as:

$$
\widehat{\mathbf{b}}-\widehat{\beta}=\mathbf{P}_{\mathbf{X}} \mathbf{D}_{i} \widehat{\phi}+\mathbf{P}_{\mathbf{X}} \mathbf{D}_{f} \widehat{\gamma}+\mathbf{P}_{\mathbf{X}} \mathbf{D}_{j} \widehat{\omega}
$$

where $\mathbf{P}_{\mathbf{X}}=\left(\mathbf{X}^{\prime} \mathbf{X}\right)^{-1} \mathbf{X}^{\prime}$ and $\mathbf{D}_{i} \widehat{\phi}, \mathbf{D}_{f} \widehat{\gamma}$, and $\mathbf{D}_{j} \widehat{\omega}$ are column vectors containing the estimates of the fixed effects for the worker, firm, and job title, respectively. This means that $\mathbf{P}_{\mathbf{X}} \mathbf{D}_{i} \widehat{\phi}$ is the coefficient of the regression of the worker fixed effects on the set of variables $\mathbf{X}$ in the base model. A similar interpretation applies to the two remaining terms in the right-hand side of equation (30). Then, we can rewrite the previous equation more succinctly as: 


$$
\widehat{\mathbf{b}}-\widehat{\beta}=\widehat{\delta}_{\phi}+\widehat{\delta}_{\gamma}+\widehat{\delta}_{\omega}
$$

Then, the change in the coefficient of interest is partitioned into the role of the different additional covariates and the conditional contribution of the worker, firm, and job title fixed effects to explain the firm labor market imperfection parameter can be identified. 